Arq. Bras. Med. Vet. Zootec., v.64, n.3, p.658-664, 2012

\title{
Níveis de treonina digestível para codorna japonesa na fase de produção
}

\author{
[Digestible threonine levels for laying japanese quail] \\ R.T. Umigi, S.L.T. Barreto, R.S. Reis, R.M. Mesquita Filho, M.S. Araújo \\ Universidade Federal de Viçosa - Viçosa, MG \\ RESUMO
}

\begin{abstract}
Avaliou-se a exigência de treonina digestível para a codorna japonesa em postura. Foram utilizadas 400 codornas, durante 63 dias. Utilizou-se delineamento inteiramente ao acaso, com cinco tratamentos, oito repetições e 10 aves por unidade experimental. A dieta basal foi deficiente em treonina, contendo 17,8\% de proteína bruta, $2.900 \mathrm{kcal}$ de EM/kg, sendo suplementada com quatro níveis de L- treonina 98\% $(0,000$; 0,$052 ; 0,104 ; 0,156$ e $0,208 \%$ ), correspondendo à relação treonina digestível:lisina digestível de 0,55 ; 0,$60 ; 0,65 ; 0,70$ e 0,75 , respectivamente. Os parâmetros estudados foram: consumo de ração, consumo de treonina, produção de ovo, peso do ovo, massa de ovos, conversão alimentar por massa de ovos, conversão alimentar por dúzia de ovos, componentes dos ovos (gema, albúmen e casca) e gravidade específica. Observou-se aumento linear $(\mathrm{P}<0,01)$ somente para o consumo de treonina. Conclui-se que, para proporcionar os melhores resultados de desempenho e qualidade de ovos, a codorna japonesa exige $0,55 \%$ de treonina digestível, para um consumo diário de $144,61 \mathrm{mg}$ de treonina digestível/ave, correspondendo à relação treonina digestível: lisina digestível de 0,55 .
\end{abstract}

Palavras-chave: aminoácido digestível, Coturnix coturnix japonica, produção de ovos, proteína ideal

\begin{abstract}
This experiment was conducted to determine the digestible threonine requirement for laying Japanese quail. Four hundred quails were used during 63 days. A completely randomized experimental design was used with five treatments, eight replicates and ten quails per experimental unit. The basal diet was deficient in threonine, containing $17.8 \%$ crude protein, $2.900 \mathrm{kcal}$ of $\mathrm{ME} / \mathrm{kg}$ and supplied with four levels of L-threonine 98\% (0.000; 0.052; 0.104; 0.156 and 0.208\%), corresponding digestible threonine: digestible lysine ratio $0.55 ; 0.60 ; 0.65 ; 0.70$ and 0.75 , respectively. The following parameters were evaluated: feed intake, threonine intake, egg production, egg weight, egg mass, feed conversion per egg mass, feed conversion per egg dozen, egg quality (yolk, albumen and shell) and specific gravity. Linear increase $(P<0.01)$ was only observed in the threonine intake. The conclusion is that the Japanese quail demand $0.55 \%$ of digestible threonine to provide the best productive performance and quality of eggs, a daily consumption of $144.61 \mathrm{mg}$ of digestible threonine/quail, corresponding to the digestible threonine: digestible lysine ratio of 0.55 .
\end{abstract}

Keywords: Coturnix coturnix japonica, digestible amino acid, egg production, ideal protein

\section{INTRODUÇÃO}

A criação de codornas tem se tornado uma atividade rentável devido às suas características relevantes, entre elas a resistência das aves ao calor, resistência à doença, exigência de pequeno espaço tanto para a instalação como para a produção, e, ainda, devido ao fato de os ovos e a carne serem nutritivos e saborosos, contribuindo com uma opção a mais de proteína na alimentação humana.

Mesmo com uma produção crescente, muito se desconhece sobre o manejo e a nutrição das codornas japonesas. A treonina é o terceiro aminoácido limitante, sendo os aminoácidos

Recebido em 30 de novembro de 2010

Aceito em 24 de novembro de 2011

E-mail: tiezoo@yahoo.com 
sulfurosos e a lisina o primeiro e o segundo, respectivamente, em dietas para aves à base de milho e de farelo de soja. Porém, segundo Mandal et al. (2006), a treonina é o segundo aminoácido limitante, em dietas para codornas utilizando-se os mesmos ingredientes, antecedido somente pela metionina.

Embora a importância da treonina seja bastante relatada na literatura, o número de pesquisas sobre o requerimento nutricional de treonina para codornas é bem escasso, quando comparadas àqueles com poedeiras comerciais, o que motivou este trabalho para determinar o nível de treonina digestível em dieta para codorna japonesa na fase de produção.

\section{MATERIAL E MÉTODOS}

O experimento foi conduzido no setor de Avicultura do Departamento de Zootecnia da Universidade Federal de Viçosa-MG, no período de maio a julho de 2007, com duração de 63 dias. $\mathrm{O}$ mesmo se encontra registrado pelo processo 17/2012, aprovado pelo Comitê de Ética para Uso de Animais do Departamento de Zootecnia da UFV.

Foram utilizadas 400 codornas japonesas fêmeas (Coturnix coturnix japonica), com 55 dias de idade e peso inicial de $178,85 \pm 0,60 \mathrm{~g}$.

O experimento foi desenvolvido em delineamento experimental inteiramente ao acaso (DIC), constituído por cinco tratamentos (níveis de treonina), com oito repetições e 10 aves por unidade experimental.

As aves foram alojadas em gaiolas de arame galvanizado dispostas em baterias $(96 \mathrm{~cm}$ de largura $x 37 \mathrm{~cm}$ de profundidade $x 16 \mathrm{~cm}$ de altura), em cinco andares e três divisórias por gaiola, sendo uma gaiola por andar. Em cada compartimento (divisória), foram alojadas dez aves, fornecendo área de $118,4 \mathrm{~cm}^{2} /$ ave. Sob o piso das gaiolas foi colocada uma bandeja de chapa metálica galvanizada, encapada com plástico, para promover a retirada das excretas.

As dietas experimentais foram formuladas à base de milho e farelo de soja. A dieta basal foi suplementada, com quatro níveis de L-treonina
$98 \%(0,000 ; 0,052 ; 0,104 ; 0,156$ e $0,208 \%)$ em substituição ao ácido glutâmico em equivalente proteico, correspondendo à relação treonina digestível:lisina digestível de 0,$55 ; 0,60 ; 0,65$; 0,70 e 0,75 , permanecendo as dietas isoproteicas, isocalóricas e isonitrogênicas. As diferenças entre os equivalentes proteicos de treonina e ácido glutâmico, nos diferentes níveis de treonina, foram compensadas pelo amido (Tab. 1). A composição química e os valores nutricionais dos ingredientes utilizados para a formulação da dieta foram segundo Rostagno et al. (2005).

Para atender às exigências dos aminoácidos foram utilizadas como base as relações aminoácido total:lisina total preconizadas pelo Nutrient... (1994), exceto para as relações metionina + cistina digestível:lisina digestível e triptofano digestível:lisina digestível, as quais foram baseadas nas recomendações de Pinto et al. (2003b) e Pinheiro et al. (2007). O nível de lisina digestível utilizado foi inferior (subótimo) àquele determinado por Pinto et al. (2003a), para que se pudesse determinar a relação treonina digestível:lisina digestível. As recomendações de cálcio, fósforo disponível e proteína bruta foram baseadas nas recomendações de Barreto et al. (2007) e Costa et al. (2007).

A ração e a água foram fornecidas à vontade durante todo o período experimental.

O manejo diário consistiu em recolher e contabilizar os ovos (foram computados diariamente o número de ovos quebrados, trincados, com casca mole e sem casca), fornecer a ração, limpar os bebedouros e os aparadores de ovos e realizar leitura das temperaturas (máxima e mínima) e umidade relativa do ar (UR).

O programa de iluminação teve seu início aos 40 dias de idade das aves, com fornecimento inicial de 14 horas de luz diária e com aumentos semanais de 30 minutos de luz até atingir 17 horas de luz diária, permanecendo assim até o término do período experimental. Este fornecimento de luz foi controlado por um relógio automático (timer), que permitiu acender e apagar as luzes automaticamente durante o período da noite e da madrugada, conforme o procedimento adotado em granjas comerciais. 
Umigi et al.

Tabela 1. Composições percentuais calculadas e valores nutricionais das dietas experimentais para codorna, na matéria natural

\begin{tabular}{|c|c|c|c|c|c|}
\hline \multirow{2}{*}{ Ingredientes $(\%)$} & \multicolumn{5}{|c|}{ Níveis de treonina digestível (\%) } \\
\hline & 0,55 & 0,60 & 0,65 & 0,70 & 0,75 \\
\hline Milho & 62,886 & 62,886 & 62,886 & 62,886 & 62,886 \\
\hline Farelo de soja $(45 \%)$ & 24,217 & 24,217 & 24,217 & 24,217 & 24,217 \\
\hline Óleo vegetal & 1,607 & 1,607 & 1,607 & 1,607 & 1,607 \\
\hline Fosfato bicálcico & 1,168 & 1,168 & 1,168 & 1,168 & 1,168 \\
\hline Calcário & 7,388 & 7,388 & 7,388 & 7,388 & 7,388 \\
\hline Sal & 0,334 & 0,334 & 0,334 & 0,334 & 0,334 \\
\hline L-Arginina $(99 \%)$ & 0,303 & 0,303 & 0,303 & 0,303 & 0,303 \\
\hline L- Lisina. $\mathrm{HCl}(79 \%)$ & 0,318 & 0,318 & 0,318 & 0,318 & 0,318 \\
\hline DL-Metionina $(99 \%)$ & 0,330 & 0,330 & 0,330 & 0,330 & 0,330 \\
\hline L- Treonina $(98 \%)$ & 0,000 & 0,052 & 0,104 & 0,156 & 0,208 \\
\hline L-Triptofano (99\%) & 0,037 & 0,037 & 0,037 & 0,037 & 0,037 \\
\hline L-Isoleucina (99\%) & 0,277 & 0,277 & 0,277 & 0,277 & 0,277 \\
\hline L-Valina $(99 \%)$ & 0,215 & 0,215 & 0,215 & 0,215 & 0,215 \\
\hline L-Glutâmico & 0,350 & 0,278 & 0,208 & 0,136 & 0,065 \\
\hline Amido & 0,300 & 0,320 & 0,338 & 0,358 & 0,377 \\
\hline Cloreto de colina $(60 \%)$ & 0,100 & 0,100 & 0,100 & 0,100 & 0,100 \\
\hline Mistura mineral $^{1}$ & 0,050 & 0,050 & 0,050 & 0,050 & 0,050 \\
\hline Mistura vitamínica $^{2}$ & 0,100 & 0,100 & 0,100 & 0,100 & 0,100 \\
\hline Surmax $^{3}$ & 0,010 & 0,010 & 0,010 & 0,010 & 0,010 \\
\hline Antioxidante $^{4}$ & 0,010 & 0,010 & 0,010 & 0,010 & 0,010 \\
\hline Total & 100,000 & 100,000 & 100,000 & 100,000 & 100,000 \\
\hline \multicolumn{6}{|l|}{ Composição calculada: } \\
\hline Energia metabolizável (kcal/kg) & 2.900 & 2.900 & 2.900 & 2.900 & 2.900 \\
\hline Proteína bruta $(\%)$ & 17,80 & 17,80 & 17,80 & 17,80 & 17,80 \\
\hline Treonina digestível (\%) & 0,550 & 0,600 & 0,650 & 0,700 & 0,750 \\
\hline Treonina total $(\%)$ & 0,632 & 0,683 & 0,734 & 0,785 & 0,836 \\
\hline Lisina digestível (\%) & 1,000 & 1,000 & 1,000 & 1,000 & 1,000 \\
\hline Metionia + cistina digestível (\%) & 0,800 & 0,800 & 0,800 & 0,800 & 0,800 \\
\hline Triptofano digestível (\%) & 0,210 & 0,210 & 0,210 & 0,210 & 0,210 \\
\hline Cálcio $(\%)$ & 3,200 & 3,200 & 3,200 & 3,200 & 3,200 \\
\hline Fósforo disponível (\%) & 0,310 & 0,310 & 0,310 & 0,310 & 0,310 \\
\hline Sódio $(\%)$ & 0,150 & 0,150 & 0,150 & 0,150 & 0,150 \\
\hline
\end{tabular}

${ }^{1}$ Composição/kg de produto: 160g de manganês, 100g de ferro, 100g de zinco, 20g de cobre, $2 \mathrm{~g}$ de cobalto, $2 \mathrm{~g}$ de iodo, $1000 \mathrm{~g}$ de excipiente q.s.p..

${ }^{2}$ Composição/kg de produto: 12.000.000U.I. de vit. A, 3.600.000U.I. de vit $\mathrm{D}_{3}$, 3.500U.I. de vit. E, 2.500mg de vit $\mathrm{B}_{1}, 8.000 \mathrm{mg}$ de vit $\mathrm{B}_{2}, 5.000 \mathrm{mg}$ de vit $\mathrm{B}_{6}, 12.000 \mathrm{mg}$ de ácido pantotênico, 200mg de biotina, 3.000mg de Vit. $\mathrm{K}$, $1.500 \mathrm{mg}$ de ácido fólico, $40.000 \mathrm{mg}$ de ácido nicotínico, $20.000 \mathrm{mg}$ de vit. $\mathrm{B}_{12}, 150 \mathrm{mg}$ de selênio, $1.000 \mathrm{~g}$ de veículo q.s.p.

${ }^{3}$ Avilamicina. ${ }^{4}$ Butil-hidróxi-tolueno.

Durante a realização do experimento, foram observados e avaliados o consumo de ração, o consumo de treonina, a produção de ovos, o peso do ovo, a massa de ovos, a conversão alimentar por massa de ovos, a conversão alimentar por dúzia de ovos, componentes dos ovos (gema, albúmen e casca) e gravidade específica.

Para mensurar o consumo de ração, ao final de cada período, de 21 dias, foi dividida a quantidade de ração consumida pelo número de aves em cada tratamento e pelo número de dias, e expresso em gramas de ração consumida/ave/dia. As sobras e os desperdícios foram pesados e descontados da quantidade de ração pesada para cada período. No caso de aves mortas durante o período, o seu consumo médio foi descontado e corrigido, obtendo-se o consumo médio verdadeiro para a unidade experimental em questão. 
A produção média de ovos foi obtida computando-se diariamente o número de ovos produzidos, incluindo os quebrados, os trincados e os anormais (ovos com casca mole e sem casca), sendo expressa em porcentagem sobre a média de aves do período (ovo/ave/dia).

O peso médio dos ovos foi obtido mediante a pesagem de todos os ovos íntegros produzidos durante o $19^{\circ}, 20^{\circ}$ e $21^{\circ}$ dias de cada período de 21 dias. O peso médio dos ovos foi multiplicado pelo número total de ovos produzidos no período, obtendo-se assim a massa total de ovos por período. Esta massa total de ovos foi dividida pelo número total de aves do período e também pelo número de dias do período, sendo finalmente expressa em gramas de ovo/ave/dia.

Foram avaliadas a conversão por dúzia de ovos, que foi expressa pelo consumo total de ração em quilogramas dividido pela dúzia de ovos produzidos $(\mathrm{kg} / \mathrm{dz})$, e a conversão por massa de ovos, que foi obtida pelo consumo de ração em quilogramas dividido pela massa de ovos produzidos em quilogramas $(\mathrm{kg} / \mathrm{kg})$.

Para quantificação dos componentes dos ovos, foram avaliados o peso da gema, o peso do albúmen e o peso da casca do ovo. Para isso, quatro ovos de cada repetição foram coletados durante o $19^{\circ}, 20^{\circ}$ e $21^{\circ}$ dias de cada período de 21 dias, de maneira aleatória do total de ovos íntegros coletados. Os ovos de cada repetição e de cada dia foram pesados individualmente, em balança com precisão de 0,001g. Após as pesagens dos ovos, estes foram identificados e, posteriormente, quebrados. A gema de cada ovo foi pesada e registrada, e a respectiva casca foi lavada e seca ao ar, para posterior obtenção do seu peso. $\mathrm{O}$ peso do albúmen foi obtido entre a diferença do peso do ovo menos o peso da gema mais o peso da casca.

Ao $16^{\circ}, 17^{\circ}$ e $18^{\circ}$ dias de cada período de 21 dias, todos os ovos íntegros coletados foram imersos e avaliados em soluções de $\mathrm{NaCl}$ com densidade variando de 1,055 a $1,100 \mathrm{~g} / \mathrm{cm}^{3}$, com intervalos de $0,005 \mathrm{~g} / \mathrm{cm}^{3}$ entre elas, sendo a densidade ou o peso específico dos ovos medido por meio de um densímetro.

Os parâmetros foram submetidos a análises estatísticas de acordo com o programa Sistema... (2007), utilizando-se os procedimentos para análise de variância e regressão. As estimativas para a exigência de treonina foram determinadas por meio de análise de regressão linear e quadrática conforme o melhor ajustamento obtido para cada variável, levando-se em consideração o comportamento biológico das aves.

\section{RESULTADOS E DISCUSSÃO}

As temperaturas máxima e mínima observadas durante o experimento foram de $23,0 \pm 2,0^{\circ} \mathrm{C}$ e $17,7 \pm 3,0^{\circ} \mathrm{C}$, respectivamente, e a umidade relativa do ar dentro do galpão foi de $80 \pm 4,3 \%$.

As médias dos dados referentes ao desempenho das codornas japonesas, alimentadas com diferentes níveis de treonina digestível na dieta, estão apresentadas na Tab. 2.

Tabela 2. Efeitos dos níveis de treonina digestível sobre o consumo de ração (CR), consumo de treonina (CT), produção de ovos (PROD), peso do ovo (PO), massa de ovos (MO), conversão alimentar por massa de ovos (CAMO) e conversão alimentar por dúzia de ovos (CADZ) de codornas japonesas

\begin{tabular}{cccccccc}
$\begin{array}{c}\text { Treonina } \\
\text { digestível }(\%)\end{array}$ & $\begin{array}{c}\text { CR } \\
(\mathrm{g} / \text { ave/dia })\end{array}$ & $\begin{array}{c}\text { CT } \\
(\mathrm{mg} / \text { ave/dia })\end{array}$ & $\begin{array}{c}\text { PROD } \\
(\%)\end{array}$ & $\begin{array}{c}\text { PO } \\
(\mathrm{g})\end{array}$ & $\begin{array}{c}\text { MO } \\
(\mathrm{g} / \mathrm{ave} / \mathrm{dia})\end{array}$ & $\begin{array}{c}\text { CAMO } \\
(\mathrm{kg} / \mathrm{kg})\end{array}$ & $\begin{array}{c}\text { CADZ } \\
(\mathrm{kg} / \mathrm{dz})\end{array}$ \\
\hline 0,55 & 26,29 & 144,61 & 93,06 & 12,28 & 11,42 & 2,302 & 0,339 \\
0,60 & 26,11 & 156,69 & 92,58 & 12,13 & 11,23 & 2,326 & 0,339 \\
0,65 & 25,94 & 168,59 & 93,29 & 12,11 & 11,30 & 2,296 & 0,334 \\
0,70 & 26,14 & 183,01 & 93,44 & 12,04 & 11,25 & 2,326 & 0,336 \\
0,75 & 26,32 & 197,39 & 93,22 & 12,20 & 11,37 & 2,314 & 0,339 \\
\hline CV $(\%)$ & 2,20 & 2,22 & 2,83 & 2,45 & 2,55 & 2,62 & 3,44 \\
\hline Significância & n.s. & $\mathrm{P}<0,01 *$ & n.s. & n.s. & n.s. & n.s. & n.s. \\
\hline
\end{tabular}

* Efeito linear $(\mathrm{P}<0,01)$ : $\hat{\mathrm{Y}}=-1,40166+2,63783 \mathrm{X} ; \mathrm{R}^{2}=0,99$

n.s. - não significativo. 
Os níveis de treonina não influenciaram $(\mathrm{P}>0,05)$ o consumo de ração (CR) das aves. Dados semelhantes para CR foram encontrados por Umigi et al. (2007), que, trabalhando com diferentes níveis de treonina digestível $(0,65$ a $0,85 \%$ ) para codorna japonesa em postura, também não verificaram efeito significativo para este parâmetro. Com os resultados de CR obtidos, pode-se inferir que o aumento nos níveis de treonina digestível, não foi suficiente para produzir imbalanço aminoacídico que resultasse na alteração do perfil plasmático do animal, ativando os mecanismos reguladores do apetite, como descrito por Harper (1970).

$\mathrm{O}$ consumo de treonina $(\mathrm{CT})$ aumentou $(\mathrm{P}<0,01)$ de forma linear, de acordo com a equação $\hat{Y}=$ $1,40166+2,63783 X ; R^{2}=0,99 . \quad A$ variação observada no CT, em razão do aumento da concentração de treonina na ração, pode ser justificada pelo fato de o $\mathrm{CR}$ não ter variado entre os tratamentos.

Não houve influência $(\mathrm{P}>0,05)$ dos níveis de treonina para produção de ovos, portanto verificou-se que o nível de $0,55 \%$ de treonina foi suficiente para a manutenção da taxa de postura $(93,06 \%)$. Resultados semelhantes foram obtidos por Umigi et al. (2007), que também não encontraram diferenças significativas para ambos os parâmetros em dietas para codornas japonesas, porém os autores concluíram que, para a manutenção do desempenho, a dieta das codornas deveria conter $0,65 \%$ de treonina digestível. Resultados superiores foram observados por Allen e Young (1980) e Shim e Lee (1993), os quais reportaram que, para uma ótima produção de ovos, as dietas das codornas deveriam conter $0,67 \%$ e $0,63 \%$ de treonina, respectivamente.
Os parâmetros peso e massa de ovos não foram influenciados $(\mathrm{P}>0,05)$ pelos teores de treonina das dietas experimentais. De forma semelhante, Umigi et al. (2007), ao avaliarem níveis crescentes de treonina $(0,65$ a $0,85 \%)$ em dietas para codorna japonesa, não encontraram variação significativa em ambos os parâmetros considerados.

Os resultados de peso de ovo, encontrados neste estudo, assemelham-se aos obtidos por Ishibashi et al. (1998) e Sá et al. (2007), os quais, avaliando os efeitos dos níveis de treonina sobre o desempenho de galinhas poedeiras, verificaram que os níveis de treonina não causaram alteração no peso dos ovos, mas observaram efeito dos níveis de treonina sobre a massa dos ovos.

Allen e Young (1980) verificaram piora na massa de ovos $(7,10$ para $6,19 \mathrm{~g}$, correspondendo a uma redução de $14,70 \%$ ), quando a L-treonina foi retirada da mistura de aminoácidos das rações das codornas.

Os níveis de treonina não influenciaram $(\mathrm{P}>0,05)$ a conversão alimentar por massa de ovos e por dúzia de ovos das aves, o que está em concordância com os resultados obtidos por Valério et al. (2000), que, estudando níveis de treonina para duas marcas comerciais de galinhas poedeiras, não encontraram diferenças para a conversão alimentar por massa e por dúzia de ovos. Por outro lado, esses resultados divergem dos obtidos por Huyghebaert e Butler (1991), que constataram efeito dos níveis de treonina sobre a conversão alimentar por massa e por dúzia de ovos em dietas de galinhas poedeiras.

Os resultados referentes aos componentes dos ovos (gema, albúmen e casca) e gravidade específica estão apresentados na Tab. 3.

Tabela 3. Componentes dos ovos: gema (G), albúmen (A) e casca (C) e gravidade específica (GE) em função dos níveis de treonina digestível nas dietas de codornas japonesas

\begin{tabular}{cccccccc}
$\begin{array}{c}\text { Treonina } \\
\text { digestível }(\%)\end{array}$ & $\begin{array}{c}\mathrm{G} \\
(\mathrm{g})\end{array}$ & $\begin{array}{c}\mathrm{G} \\
(\%)\end{array}$ & $\begin{array}{c}\mathrm{A} \\
(\mathrm{g})\end{array}$ & $\begin{array}{c}\mathrm{A} \\
(\%)\end{array}$ & $\begin{array}{c}\mathrm{C} \\
(\mathrm{g})\end{array}$ & $\begin{array}{c}\mathrm{C} \\
(\%)\end{array}$ & $\begin{array}{c}\mathrm{GE} \\
\left(\mathrm{g} / \mathrm{cm}^{3}\right)\end{array}$ \\
\hline 0,55 & 3,66 & 29,04 & 7,90 & 62,75 & 1,03 & 8,21 & 1,075 \\
0,60 & 3,64 & 29,01 & 7,88 & 62,83 & 1,02 & 8,16 & 1,075 \\
0,65 & 3,59 & 28,70 & 7,90 & 63,12 & 1,02 & 8,18 & 1,075 \\
0,70 & 3,58 & 28,83 & 7,84 & 63,07 & 1,00 & 8,10 & 1,075 \\
0,75 & 3,65 & 28,87 & 7,96 & 63,02 & 1,02 & 8,11 & 1,075 \\
\hline CV $(\%)$ & 3,30 & 2,24 & 2,42 & 1,03 & 3,88 & 2,48 & 0,11 \\
\hline Significância & n.s. & n.s. & n.s. & n.s. & n.s. & n.s. & n.s. \\
\hline
\end{tabular}


Não se observou influência $(\mathrm{P}>0,05)$ dos níveis de treonina digestível sobre nenhuma das variáveis de componentes dos ovos avaliados. Efeito similar dos níveis de treonina da dieta sobre os componentes dos ovos de codornas também foi relatado por Umigi et al. (2007) quando ministraram dietas com diferentes níveis de treonina digestível para codorna japonesa.

Trabalhando com galinhas poedeiras leves e semipesadas, de segundo ciclo de produção, Schmidt (2006) não observou efeito significativo dos níveis de treonina na ração para os componentes dos ovos, em ambas as linhagens, com exceção da porcentagem de casca, que apresentou efeito quadrático para a linhagem leve.

Segundo Kul e Seker (2004), resultados divergentes dos obtidos neste experimento, encontrados na literatura, relacionados com a qualidade dos ovos, poderiam ser devido às diferenças entre estrutura genética, condições de sanidade, idade da ave, alimentação e condições ambientais e de manejo.

Os níveis de treonina não influenciaram $(\mathrm{P}>0,05)$ o resultado da gravidade específica, o que indica que o nível de $0,55 \%$ de treonina não prejudicou a qualidade da casca do ovo.

De acordo com todas as variáveis, o nível de $0,55 \%$ de treonina digestível foi suficiente para se alcançar resultados satisfatórios, tanto no desempenho quanto na qualidade dos ovos de codorna.

\section{CONCLUSÃO}

O nível de $0,55 \%$ de treonina digestível, correspondente a um consumo diário de $144,61 \mathrm{mg}$ de treonina digestível/ave e a uma relação de 55\% com a lisina digestível, atendeu as exigências de codornas japonesas em postura.

\section{REFERÊNCIAS}

ALLEN, N.K.; YOUNG, R.J. Studies on the amino acid protein requirements of laying japanese quail (Coturnix coturnix japonica). Poult. Sci., v.59, p.2029-37, 1980.
BARRETO, S.L.T.; PEREIRA, C.A.; UMIGI, R.T. et al. Determinação da exigência nutricional de cálcio de codornas japonesas na fase inicial do ciclo de produção. Rev. Bras. Zootec., v.36, p.6878, 2007.

COSTA, C.H.R.; BARRETO, S.L.T.; MOURA, W.C.O. et al. Níveis de fósforo e cálcio em dietas para codornas japonesas em postura. Rev. Bras. Zootec., v.36, supl., p.2037-2046, 2007.

HARPER, A.E.; BENEVENGA, N.J.; WOHLHUETER, R.M. Effects of ingestion of disproportionate amounts of amino acids. Phys. Rev., v.50, p.428-558, 1970.

HUYGHEBAERT, G.; BUTLER, E.A. Optimun threonine requirements of laying hens. Brit. Poult. Sci., v.32, p.575-582, 1991.

ISHIBASHI, T.; OGAWA, T.; ITO, S. et al. Threonine requirements of laying hens. Poult. Sci., v.77, p.998-1002, 1998.

KUL, S.; SEKER, I. Phenotypic correlations between some external and internal egg quality traits in the japanese quail (Coturnix Coturnix japonica). Poult. Sci., v.3, p.400-405, 2004.

MANDAL, A.B.; KAUR, S.; JOHRI, A.K. et al. Response for growing japanese quails to dietary concentration of L-threonine. J. Sci. Food Agric., v.86, p.793-798, 2006.

NUTRIENT requirements of poultry. 9.ed. Washington: National Academy of Sciences, 1994. 155p.

PINHEIRO, S.R.F.; BARRETO, S.L.T.; UMIGI, R.T. et al. Efeito dos níveis de triptofano digestível para codornas japonesas em postura sobre os parâmetros de qualidade de ovos. Rev. Bras. Cienc. Avic., Supl. 9, p.78, 2007.

PINTO, R.; DONZELE, J.L.; FERREIRA, A.S. et al. Exigência de metionina mais cistina para codornas japonesas em postura. Rev. Bras. Zootec., v.32, p.1166-1173, 2003b.

PINTO, R.; FERREIRA, A.S.; DONZELE, J.L. et al. Exigência de lisina para codornas japonesas em postura. Rev. Bras. Zootec., v.32, p.1182$1189,2003 \mathrm{a}$.

ROSTAGNO, H.S.; ALBINO, L.F.T.; DONZELE, J.L. et al. Tabelas Brasileiras para Aves e Suínos. Composição de Alimentos e Exigências Nutricionais. Viçosa: Editora UFV, 2005. 186p. 
SÁ, L.M.; GOMES, P.C.; CECON, P.R. et al. Exigência nutricional de treonina digestível para galinhas poedeiras no período de 34 a 50 semanas de idade. Rev. Bras. Zootec., v.36, p.1846-1853, 2007.

SCHMIDT, M. Níveis nutricionais de lisina, de metionina +cistina e de treonina digestíveis para galinhas poedeiras no $2^{\circ}$ ciclo de produção. 2006. 101p. Tese (Doutorado em Zootecnia) Universidade Federal de Viçosa.

SHIM, K.F.; LEE, T.K. Effect of Dietary essential amino acids on egg production of laying Japanese quail. Sing. J. Prim. Ind., v.21, p.72-75, 1993.
UMIGI, R.T.; BARRETO, S.LT.; DONZELE, J.L. et al. Níveis de treonina digestível em dietas para codorna japonesa em postura. Rev. Bras. Zootec., v.36, p.1868-1874, 2007.

UNIVERSIDADE FEDERAL DE VIÇOSA, Sistema para análises estatísticas- SAEG , versão 9.1. Viçosa: Fundação Arthur Bernardes, 2007.

VALÉRIO, S.R. ; SOARES, P.R. ; ROSTAGNO, H.S. et al. Determinação da exigência nutricional de treonina para poedeiras leves e semipesadas. Rev. Bras. Zootec., v.29, p.518-524, 2000. 